10. Фещенко Ю. І. Епідеміологія туберкульозу у світі, сучасні підходи до організації протитуберкульозних заходів / Ю. І. Фещенко, В. М. Мельник, В. Г. Матусевич // Український пульмонологічний журнал. - 2003. - № 4. - С. 5-10.

11. Фещенко Ю. І. Сучасні методи діагностики, лікування і профілактики туберкульозу / Ю. І. Фещенко, В. М. Мельник. - К. : Здоров'я, 2004. - 904 с.

Цепюк Любовь, Чмух Яна, Абрамчук Ольга. Особенности показателей крови больных туберкулезом мужчин Ровенской области. В статье рассмотрены особенности показателей периферической крови больных туберкулезом мужчин. Показано, что элементы лейкоцитарной фракции крови реагировали на туберкулезный процесс более активно, сравнительно с показателями красной крови. Установлено, что средние показатели скорости оседания эритроцитов во всех группах обследуемых были выше нормы. У больных с различными формами туберкулеза обнаружены значительные отклонения в лейкоцитарной формуле и количестве лейкоцитов.

Ключевые слова: туберкулез, интоксикация, кровь, патологический процесс, эритроциты, лейкоциты.

Tsepyuk Lyubov, Chmuch Yana, Abramchuk Olga. The Blood Parameters Analysis of Pulmonary Tuberculosis of Male Patients in the Rivne. The features of the blood parameters of male patients in the Rivne hospital were analyzed. The overall analysis of the blood with different forms of tuberculosis showed different deviations depending on the form of the pathological process. It was shown that leukocyte fraction responded to TB process more active compared with the red blood. The results showed that at the time of hospitalization among all patients were found significant deviations in leukocyte formula and the number of leukocytes. The average erythrocyte sedimentation rate of male was higher in all groups compared to normal.

Key words: tuberculosis, intoxication, disease process, blood, erythrocytes, leukocytes.

Стаття надійшла до редколегії 09.09.2016 р.

УДК 616.155.194-055.2

Тетяна Качинська, Люда Монюк

\title{
Вплив умісту гемоглобіну в крові на кардіореспіраторну систему жінок
}

Вивчено вплив умісту гемоглобіну в крові на функціональний стан кардіореспіраторної системи жінок зрілого віку. Адаптаційні та резервні можливості серцево-судинної системи характеризувалися кращими показниками в осіб із $\mathrm{B}_{12}$-фолієводефіцитною анемією й нормальним умістом гемоглобіну, порівняно 3 жінками із залізодефіцитною анемією.

Ключові слова: залізодефіцитна анемія, В 12 -фолієводефіцитна анемія, гемоглобін.

Постановка наукової проблеми та їі значення. Вивчення біохімічних основ різних захворювань $\mathrm{i}$ патологічних станів організму людини - одне $з$ основних завдань біології та медицини [15, 1073-1080]. Процес розвитку анемічних станів пов'язаний із кількісними і якісними змінами в еритроцитах крові [4, 40-42]. 3а сучасними уявленнями, залізодефіцитна анемія (ЗДА, шифр за МКX-10 - Д50) - це захворювання, яке виникає внаслідок дефіциту заліза в організмі під час порушення його надходження, засвоєння або патологічних утрат та якому притаманні зниження рівня гемоглобіну в одиниці об'єму крові, зменшення середньої концентрації гемоглобіну в еритроцитах, зниження вмісту заліза в сироватці крові, клінічні прояви анемічної гіпоксії, сідеропенії й метаболічної інтоксикації [10]. Дефіцит заліза несприятливо впливає на функції багатьох систем організму (серцево-судинної, нервової, травного тракту, дихальної, імунної та ін.). Під час анемічного стану страждають система адаптації, формування й реалізація репродуктивної функції, інтелектуальний розвиток жінки [13, 66].

Аналіз дослідження цієї проблеми. Залізодефіцитна анемія (ЗДА) - розповсюджений патологічний стан. За даними МОЗ України (2000р.), поширеність залізодефіцитної анемії складала 1163,9 на 100000 населення, зокрема серед дорослих - 610,2, серед дітей - 3598,6 на 100000 населення. Захворюваність на цю патологію сягає 160,0 серед дорослих та 1479,9 серед дітей на 100000 населення. Близько 20 \% мешканців геохімічних провінцій ( Полісся, Поділля тощо) мають ЗДА, чи латентний дефіцит заліза. Подолання залізодефіцитних анемій та латентного залізодефіциту - найактуальніше серед завдань

() Качинська Т., Монюк Л., 2016 
сучасної медицини медицини [1, 57-60]. В Україні рівень захворюваності на залізодефіцитну анемію $€$ надзвичайно високим і немає тенденції до зниження. Зважаючи на таку негативну динаміку захворюваності, проблема діагностики, лікування й профілактики залізодефіцитних станів набуває надзвичайної актуальності $[14,23-28]$. Поєднання ЗДА $з$ іншими захворюваннями внутрішніх органів, з одного боку, призводить до виникнення синдрому взаємного обтяження захворювань $\mathrm{i}$ тяжчого їх перебігу, а з іншого - ускладнює повноцінне лікування як захворювань внутрішніх органів, так і самої ЗДА [2, 62-64]. Актуальність дослідження визначається й соціально-медичною значущістю проблеми, оскільки на ЗДА хворіють працездатні люди, діти та жінки репродуктивного віку.

За даними ВООЗ, від дефіциту заліза (ДЗ) потерпає кожен п’ятий мешканець Землі [16, 537-545]. Особливо гостро постала ця проблема в дівчаток підліткового віку й жінок репродуктивного віку, коли за фізіологічних умов значно зростає потреба в білках, вітамінах, мікроелементах. Серед факторів, що зумовлюють розвиток ЗДА в осіб жіночої статі, виділяють несприятливий перинатальний фон, гормональний дисбаланс, підвищені фізіологічні втрати (особливо під час менструацій), супутні захворювання, серед яких найбільшу роль відіграють патології з боку шлунково-кишкового тракту (хронічні гастрити, гастродуоденіти) і гінекологічні захворювання, переважно пов'язані з хронічною крововтратою $[11,571]$. Важко переоцінити актуальність проблеми, ураховуючи важливе значення заліза в процесах життєзабезпечення організму жінки.

Більшість адаптаційних процесів прямо чи опосередковано знаходить своє відображення в змінах гематологічних показників. Серцево-судинна система 3 iї багаторівневим регулюванням - найбільш тонкий індикатор функціонального стану організму [9, 120-122]. Вивчення особливостей механізмів загальної стійкості організму до різної концентрації гемоглобіну в крові має велике значення [5]. Проте, незважаючи на досить широкий спектр вивчення проблеми, адаптаційні й резервні можливості, а також інтегральні показники серцево-судинної системи та причини їх змін залишаються недостатньо вивченими.

У комплексі фізіологічних процесів, які постійно відбуваються в організмі й забезпечують споживання кисню та видалення двоокису вуглецю, зовнішнє дихання посідає важливе місце [6, 161-165]. Функції апарату зовнішнього дихання розкрито в численних наукових працях, однак відомості щодо особливостей зовнішнього дихання в осіб постпубертатного віку з різним умістом гемоглобіну в крові обмежені.

Тому, мета роботи полягає у вивченні впливу різного вмісту гемоглобіну в крові на функціональний стан кардіореспіраторної системи жінок зрілого віку.

Матеріали та методи дослідження. Дослідження проведено на 30 особах жіночої статі віком $28-32(30 \pm 0,7)$ роки, людях, котрі характеризуються різною концентрацією гемоглобіну в крові. Дослідження проводили в робочі дні тижня, у проміжку часу з 8.00 до 11.00.

Усіх обстежуваних поділено на три групи: I - контрольна група, жінки (10 осіб) із нормальним умістом гемоглобіну в крові (уміст $\mathrm{Hb}-115-145$ г/л); II - жінки (10 осіб) із залізодефіцитною анемією; III - жінки (10 осіб) із $\mathrm{B}_{12}$-фолієво-дефіцитною анемією.

Визначення концентрації гемоглобіну в крові досліджуваних проводили ціанметгемоглобіновим фотометричним методом (В. В. Меншиков, 1982) у лабораторії крові Волинської обласної клінічної лікарні (с. Боголюби). Основа методу - перетворення складних форм (оксигемоглобіну, карбоксигемоглобіну, метгемоглобіну та ін.) гемоглобіну, що міститься в еритроцитах, на ціангемоглобін [8, 3-7].

У процесі проведення дослідження здійснювали вимірювання антропометричних показників (ріст, маса тіла, об'єм грудної клітки на вдиху й у стані спокою). Для вивчення стану серцево-судинної системи використовувалися такі показники, як частота серцевих скорочень, що визначалася пальпататорно; артеріальний тиск, вимірювання якого виконували за допомогою непрямого методу Н. С. Короткова; систолічний об'єм крові (СОК) і хвилинний об'єм крові (ХОК), які визначали за допомогою відповідних формул [7].

Для визначення резервно-функціональних можливостей кардіоваскулярної системи використовували індекс Робінсона, індекс Руф'є, оцінку рівня функціонального стану (РФС) системи кровообігу та Адаптаційний потенціал ССС [7].

Визначення функціональних показників дихальної системи здійснювали методом спірометрії за допомогою повітряного спірометра. Вимірювали життєву ємність легень (ЖЄЛ), дихального об'єму (ДО), хвилинного об'єму дихання (ХОД). Оцінку стану дихальної системи проводили за допомогою проби Штанге та проби Генчі-Собразе, а оцінку функціонального стану кардіореспіраторної системи - за допомогою індексу Скибінські [7]. 
Статистичну обробку проводили, застосовуючи програми MS Excel 2000. Визначали нормальність розподілу даних. Для парного порівняння груп використовували критерій достовірності Стьюдента (t) i Мана-Уітні (W) та показник достовірності при порівнянні середніх величин (p). Різницю між двома середніми величинами вважали достовірною при значення $\mathrm{t} \geq 2,0 \mathrm{i} \mathrm{p} \leq 0,05$. Визначали середнє значення показника (M), величину середньої похибки ( \pm m) і коефіцієнт кореляції Пірсона (r) [3].

Виклад основного матеріалу й обгрунтування отриманих результатів дослідження. Аналіз рівня гемоглобіну в крові жінок трьох досліджуваних груп засвідчив, що в осіб із нормальною концентрацією $\mathrm{Hb}$ цей показник мав статистично достовірно вище значення, порівняно 3 досліджуваними II і III груп.

Результати показників серцево-судинної системи в осіб контрольної та двох експериментальних груп засвідчили, що частота серцевих скорочень у представників I групи мала статистично достовірно вищі показники $(75 \pm 1,0$ уд/хв), порівняно 3 жінками, котрі характеризуються ЗДА $(66 \pm 2,8$ уд/хв) та $\mathrm{B}_{12}$-дефіцитною анемією $\left(68 \pm 2,5\right.$ уд/хв). Аналіз показників ЧСС у жінок із ЗДА й $\mathrm{B}_{12}$-дефіцитною анемією не виявив статистично достовірної різниці.

Аналіз інтегральних показників у досліджуваних різних груп показав, СОК і ХОК мали вищі показники в досліджуваних, які характеризуються нормальним умістом гемоглобіну в крові, що вказує на більший викид крові в кров'яне русло. Так, в осіб контрольної групи показники систолічного

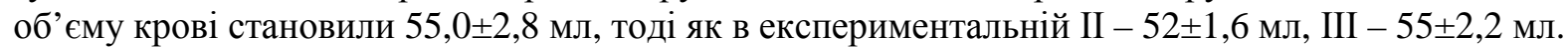

Дані ХОК мали подібну тенденцію й характеризувалися статистично достовірно вищими результатами в респондентів контрольної групи, порівняно з особами експериментальних груп (II -

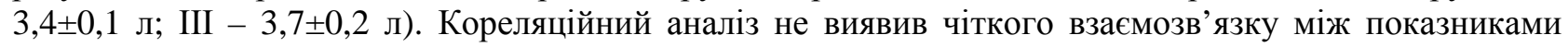
ХОК і рівнем гемоглобіну в досліджуваних трьох груп.

Потрібно відзначити, що незалежно від виявленої різниці між інтегральними показниками серцево-судинної системи в осіб контрольної та експериментальних груп показники СОК не відповідають віковим параметрам, тоді як ХОК лише в жінок із залізодефіцитною анемією не збігається 3 даними норми.

Аналіз адаптаційних можливостей ССС у досліджуваних засвідчив вищі іiі резерви в осіб із нормою $\mathrm{Hb}$ та $\mathrm{B}_{12}$-фолієводефіцитною анемією. Так, за індексом Робінсона вищі показники просте-

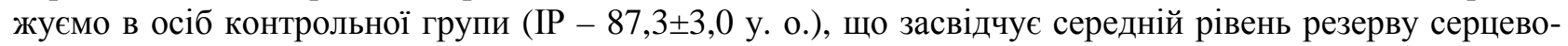
судинної системи; нижчі показники, проте з таким самим рівнем резерву, зафіксовано в жінок II й III груп. У контрольній групі, порівняно із ЗДА, зафіксовано статистично достовірно вищі результати (рис. 1 А).

A

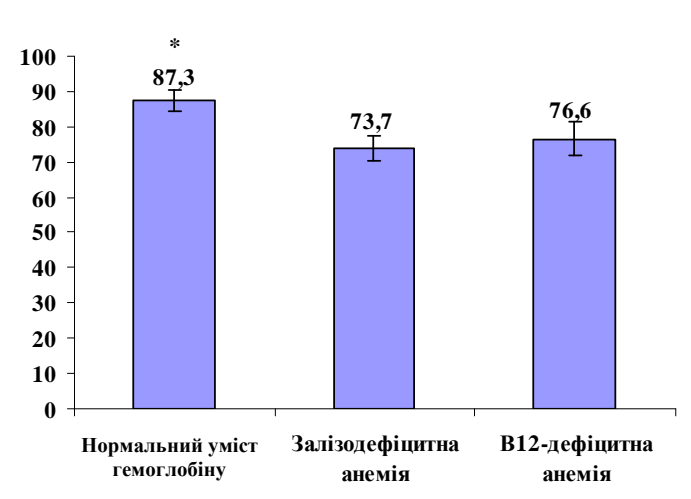

Б

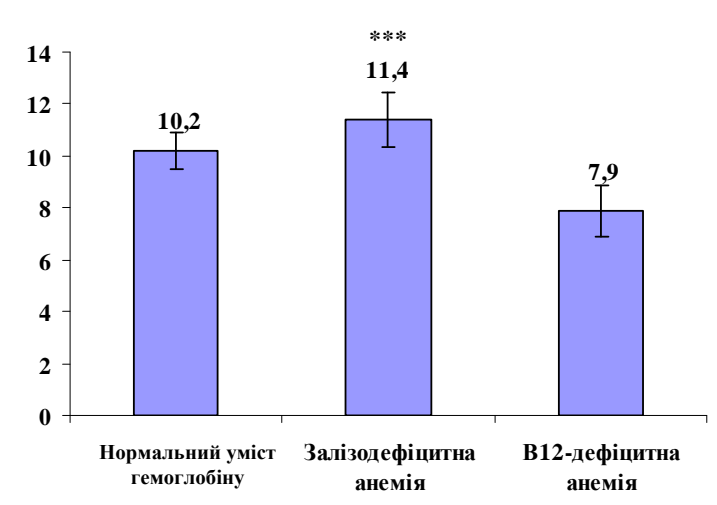

Рис. 1. Показники індексу Робінсона (А) та індексу Руф'є (Б) у жінок контрольної й експериментальних груп (у. о.).

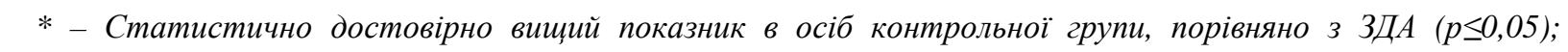

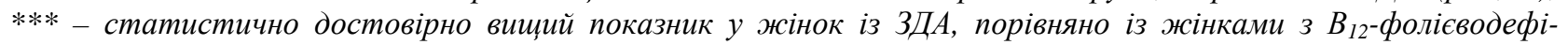
цитною анемією $(p \leq 0,05)$. 
Під час аналізу індексу Руф'є статистично достовірно вищі значення зафіксовано в осіб із ЗДА $\left(11,4 \pm 1,0\right.$ у. о.), порівняно 3 жінками із $\mathrm{B}_{12}$-фолієводефіцитною анемією $(7,9 \pm 1,0$ у. о.), що свідчить про задовільний рівень резервів серцево-судинної системи в осіб ЗДА та хороший - у досліджуваних iз нормою $\mathrm{Hb}$ i $\mathrm{B}_{12}$-фолієводефіцитною анемією (рис. 1 Б). Кореляційний аналіз виявив взаємозв'язок між рівнем гемоглобіну й резервними можливостями серцево-судинної системи в осіб контрольної групи $(\mathrm{r}=0,58)$.

Рівень функціонального стану серцево-судинної системи, незалежно від концентрації гемоглобіну в крові досліджуваних груп, був низьким, проте в жінок із $\mathrm{B}_{12}$-фолієводефіцитною анемією показник мав вищі результати $(0,355 \pm 0,06)$, порівняно з досліджуваними з інших груп. У цій же групі виявлено кореляцію між умістом гемоглобіну в крові та рівнем функціонального стану $(\mathrm{r}=0,63)$. Адаптаційний потенціал системи кровообігу в жінок різних досліджуваних груп на задовільному рівні адаптації в осіб із $\mathrm{B}_{12}$-фолієводефіцитною анемією $(2,1 \pm 0,1)$, тоді як у досліджуваних двох інших груп спостерігали напругу механізмів адаптації. Отже, стан серцево-судинної системи, адаптаційні й резервні можливості характеризуються кращими показниками в осіб із $\mathrm{B}_{12}$-фолієводефіцитною анемією та нормальним умістом гемоглобіну, порівняно $з$ жінками з залізодефіцитною анемією.

Аналіз показників ЖЕЛ у досліджуваних виявив вищі значення в жінок контрольної групи $(3,06 \pm 0,12$ л), тоді як в осіб II й III експериментальних груп показник характеризувався статистично

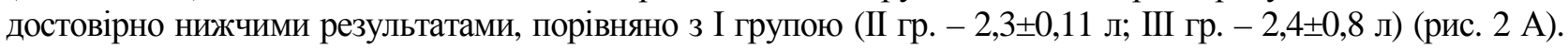
Кореляційний аналіз засвідчив чітку взаємозалежність між показниками ЖЄЛ у жінок контрольної групи та з ЗДА й рівнем умісту гемоглобіну в крові ( $-\mathrm{r}=0,23$; II $-\mathrm{r}=0,51)$. Порівняння результатів дослідження в жінок різних груп із середніми віковими нормами цього показника підтвердило, що значення ЖЕЛ лише в жінок із нормальним умістом гемоглобіну відповідає «нормі», тоді як представниці двох експериментальних груп мали нижчі від «норми» значення.

A

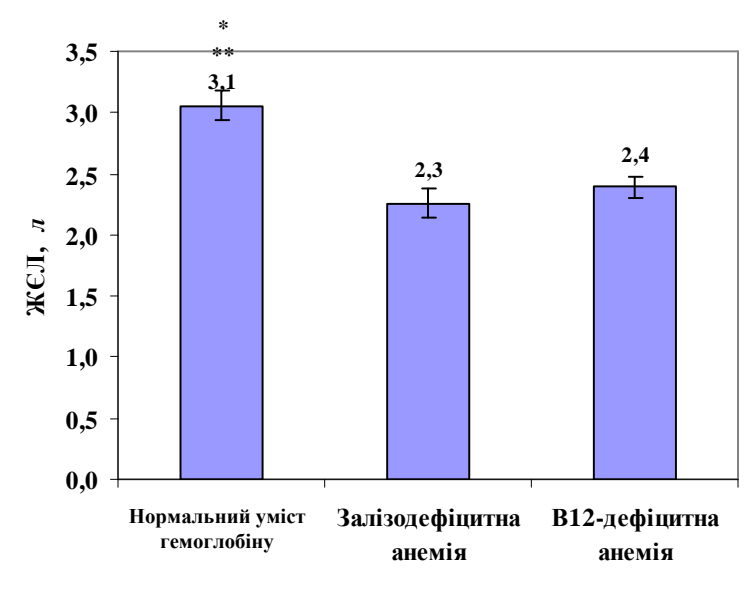

Б

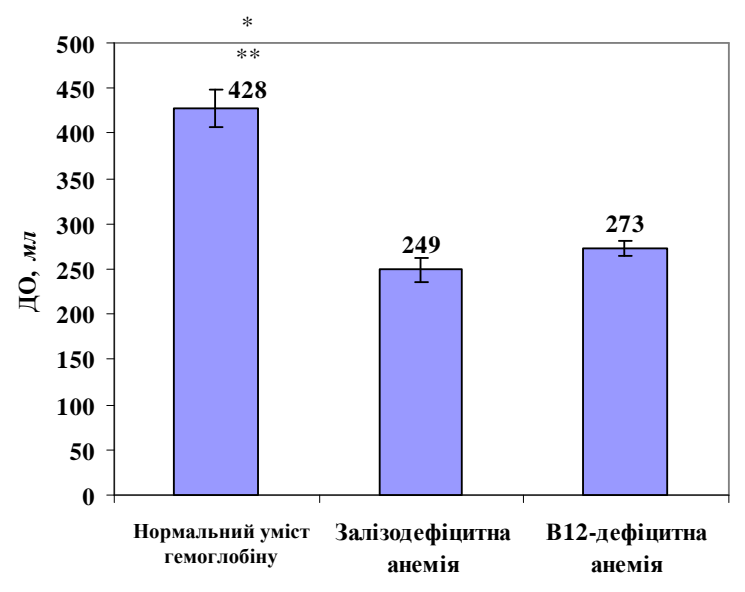

Рис. 2. Показники життєвої ємності легень (А) та дихального об'єму (Б) у жінок контрольної й експериментальних груп

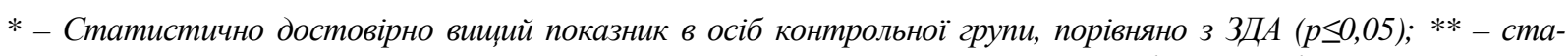
тистично достовірно вищий показник в осіб контрольної групи, порівняно з $B_{12}$-фолієводефіцитною анемією $(p \leq 0,05)$.

Показники зовнішнього дихання, а саме дихальний об'єм повітря в жінок із нормальним умістом гемоглобіну в крові перебуває в межах вікової норм. У жінок контрольної групи показник ДО становить $428 \pm 20,9$ мл, а в осіб із ЗДА та $\mathrm{B}_{12}$-фолієводефіцитною анемією достовірно нижчий,

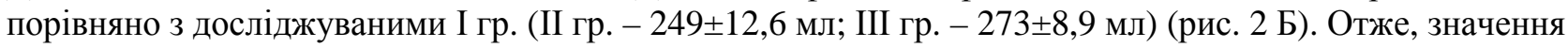
ДО в жінок II та III груп не відповідають середньогруповим показникам норми для цього віку. Кореляційний аналіз виявив взаємозалежність між значеннями ДО й умістом гемоглобіну в крові лише в осіб із залізодефіцитною анемією - $\mathrm{r}=0,35$. 
Важливий показник функціонального стану дихальної системи - частота дихання (ЧД). ІІї збільшення вказує на неглибоке поверхове дихання, де задіяна лише незначна частина обсягу легень, що вважається поганим у функціонуванні дихальної системи [6, 161-165].

У досліджуваних, які характеризуються низьким умістом гемоглобіну в крові, відзначено збільшення частоти дихальних рухів, порівняно 3 жінками контрольної групи. Так, достовірно вищі значення ЧД, порівняно з I та III групами, зафіксовано в осіб із ЗДА $(22 \pm 0,92 \mathrm{n} / \mathbf{\text { в}})$ (рис. 3 А). У жінок із нормальним умістом гемоглобіну в крові відмічено достовірно менші значення ЧД, порівняно 3 особами II й III експериментальних груп $(16 \pm 0,47$ n/хв). Показникам «норма» для цієї вікової групи відповідали результати лише в представниць контрольної групи.

A

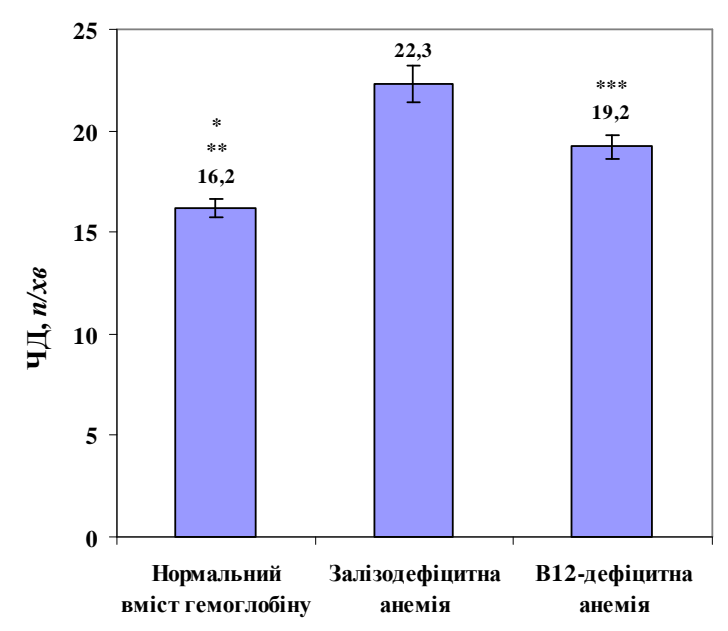

Б

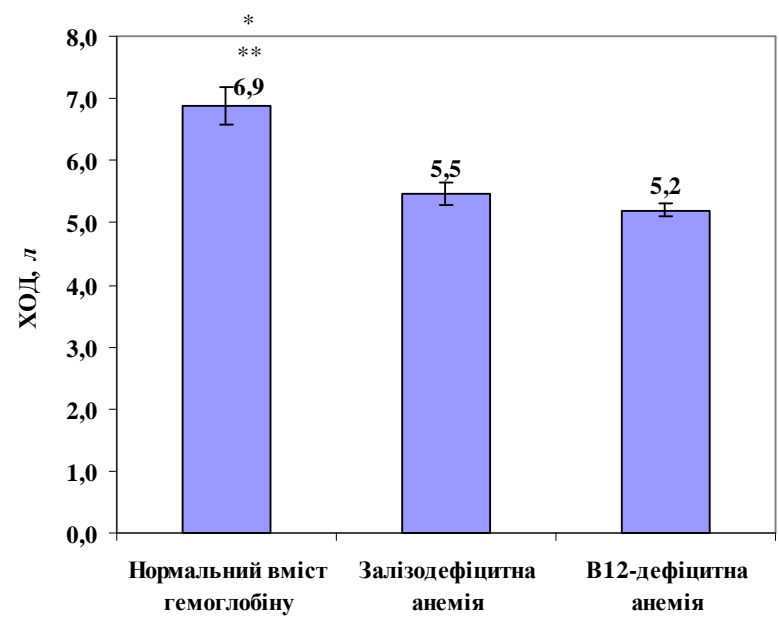

Рис. 3. Показники частоти дихання (А) та хвилинного об' 'му дихання (Б) в жінок контрольної й експериментальних груп

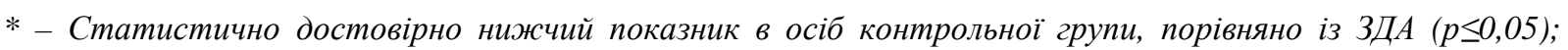
** - статистично достовірно нижчий показник в осіб контрольної групи, порівняно з $B_{12}$-фолієводефіцитною анемією $(p \leq 0,05)$; *** - статистично достовірно нижчий показник в осіб з $B_{12}$-фолієводефіцитною анемією, порівняно із ЗДА ( $p \leq 0,05)$.

Хвилинний об' $є$ м дихання, незалежно від групи досліджуваних, перебував у межах норми й коливався в діапазоні від $6,9 \pm 0,30$ л в осіб контрольної групи до $5,2 \pm 0,1$ л у жінок із $\mathrm{B}_{12}$-фолісводефіцитною анемією (рис. 3. Б). Проте жінки з нормальним умістом гемоглобіну в крові характеризувалися статистично достовірно вищими значеннями ХОД, порівняно 3 досліджуваними II й III експериментальних груп.

Аналіз функціональної проби Штанге засвідчив, що статистично достовірно вищі значення мали жінки із нормальним умістом гемоглобіну в крові $\left(43,5 \pm 1,01\right.$ c) і з В $_{12}$-фолієводефіцитною анемією

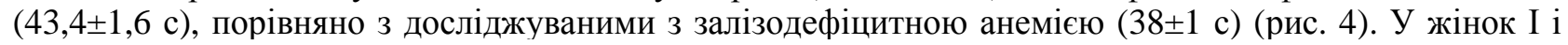
III експериментальних груп, згідно з тестом Штанге, - добрий рівень функціонування дихальної системи, а в жінок із ЗДА - середній.

Аналіз функціональної проби Генчі в досліджуваних різних груп виявив статистично достовірно вищі іï значення в контрольній групі $(43,5 \pm 1,01$ c), порівняно 3 досліджуваним II $(39,4 \pm 0,94$ c) i III $(37,1 \pm 2,32$ с) експериментальних груп (рис. 4). Згідно з оцінною школою цього показника, у представниць контрольної групи хороший функціональний стан дихальної системи, тоді як у жінок із ЗДА та $\mathrm{B}_{12}$-фолієводефіцитною анемією - середній. Незалежно від рівня вмісту гемоглобіну в крові досліджуваних жінок результати функціональних проб Штанге й Генчі відповідають середньогруповим показникам норми.

Аналіз індексу Скібінські, який указує на функціональний рівень кардіореспіраторної системи, у жінок із різним умістом гемоглобіну в крові виявив задовільний іï стан у представниць усіх експериментальних груп, за бальною шкалою оцінювання. Згідно з результатами дослідження цього індексу в осіб із нормальним вмістом гемоглобіну, порівняно з жінками із ЗДА, відзначено статистично 


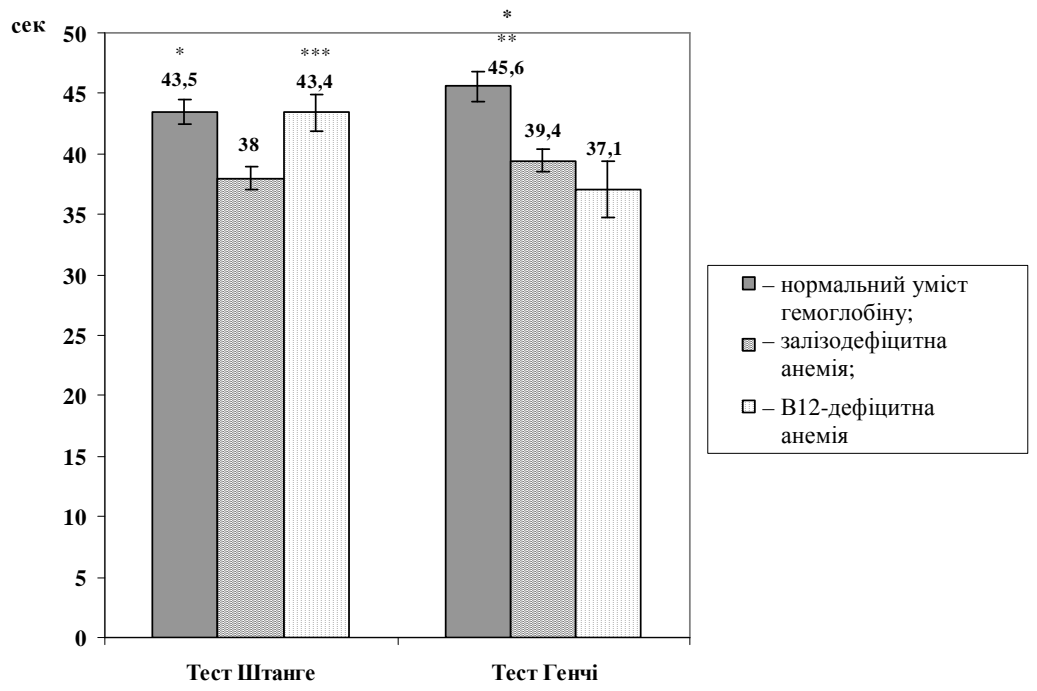

Рис. 4. Показники Тесту Штанге та Генчі (с) у жінок контрольної та експериментальних груп

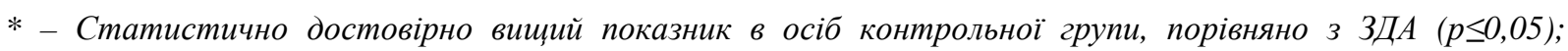
** - статистично достовірно виий показник в осіб контрольної групи, порівняно з $B_{12}$-фолієводефіцитною анемією $(p \leq 0,05)$; *** - статистично достовірно вищий показник в осіб із $B_{12}$-фолієводефіцитною анемією, порівняно з ЗДА $(p \leq 0,05)$.

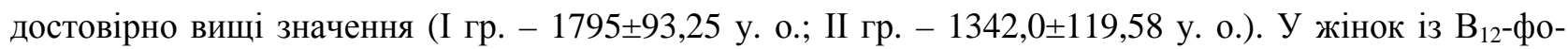
лієводефіцитною анемією значення індексу Скибінські становило $1553 \pm 81,3$ у. о. Кореляційний аналіз виявив чітку взаємозалежність між умістом гемоглобіну в крові жінок із залізодефіцитною анемією та значенням індексу Скибінські (r=0,34).

Зниження обмінних процесів у периферичних тканинах, що виникає в результаті зменшення кількості кисню, який надходить у клітини, зменшує вимоги до серцевого м'яза й відповідно до цього зменшується його робота: знижуються частота серцевих скорочень та серцевий викид, зменшується швидкість кровотоку. Як наслідок, зменшується об’єм крові, що циркулює в судинному руслі [12].

Потреба в кисні - головний фактор місцевої регуляції коронарного кровотоку. Кровотік у коронарних судинах перебуває в прямій пропорційній залежності від потреби серцевого м'яза в кисні. Зазвичай серцевий м'яз поглинає близько 70 \% загальної кількості кисню з артеріальної крові. Оскільки зменшується об'єм крові, що циркулює в судинному руслі, серцевий м'яз та інші тканини організму не отримують достатньо кількості кисню. Зовнішні прояви цих процесів - блідість, а інколи й синюшність шкіри, що є одним із симптомів анемічного стану. У кінцевому рахунку низька концентрація кисню в крові порушує мозкову та серцеву діяльність [5]. У результаті розвиваються розлади свідомості й порушення серцевого ритму. Супровідним явищем є збільшення концентрації вуглекислого газу, що викликає підвищення кислотності крові, яка впливає на всі органи, особливо серце та мозок. Очевидно, організм прагне звільнитися від надлишку вуглекислого газу неглибоким швидким диханням, що зафіксоване в жінок із залізодефіцитною й $\mathrm{B}_{12}$-фолієводефіцитною анемією.

Висновки та перспективи подальшого дослідження. Жінки із залізодефіцитною та $\mathrm{B}_{12}$-фолієводефіцитною анеміями, порівняно з досліджуваними контрольної групи, характеризувалися зниженням показників ЧСС, АТ, СОК і ХОК.

Адаптаційні й резервні можливості серцево-судинної системи характеризувалися кращими показниками в осіб із $\mathrm{B}_{12}$-фолієводефіцитною анемією та нормальним умістом гемоглобіну, порівняно $з$ жінками з залізодефіцитною анемією.

За пробою Штанге представниці контрольної групи й із $\mathrm{B}_{12}$-фолієводефіцитною анемією характеризуються добрим рівнем можливостей, тоді як досліджувані із ЗДА - середнім. За показниками тесту Генчі, згідно з оцінною шкалою, рівень можливостей оцінюють як середній в осіб II й III груп і нормальний - у жінок контрольної групи. Індекс Скибінські виявив задовільний стан кардіореспіраторної системи в жінок із різною концентрацією гемоглобіну в крові. 
У подальшому планується вивчення вмісту гемоглобіну на стан кардіореспіраторної системи чоловіків.

\section{Джерела та література}

1. Буданов П. В. Проблемы профилактики и лечения железодефицитных анемий у беременных / П. В. Буданов // Журнал «Трудный пациент». - №8. - 2009. - С. 57-60.

2. Видиборець С. В. Сучасні препарати заліза та їхнє клінічне застосування / С. В. Видиборець // Ліки України. - 1999. - №12. - С. 62-64.

3. Елисеева И. И. Общая теория статистики / И. И. Елисеева. - М. : Финансы и статистика, 2004. -656 с.

4. Ёлкина Н. М. Метаболические изменения в еритроцитах больных цирозом печени / Н. М. Ёлкина, В. В. Казакова // Ученые записки Таврического національного универитета им. В. И. Вернадского. Симферополь, 2006. - Т. 19 (58), № 1. - С. 40-42.

5. Заболевания вегетативной нервной системы / [Л. М. Вейн, Т. Г. Вознесенская, В. Л. Голубев и др.]. М. : Медицина, 1991. - 624 с.

6. Коцан І. Я. Особливості функції апарату зовнішнього дихання у молоді постпубертатного періоду онтогенезу / І. Я. Коцан, Т. В. Крамаревич // Фізика живого. - 2008. - Т. 16, № 1. - С. 161-165.

7. Маліков М. В. Функціональна діагностика у фізичному вихованні і спорті : навч. посіб. [для студ. вищ. навч. закл.] / М. В. Маліков, А. В. Сватьєв, Н. В. Богданова. - Запоріжжя : ЗДУ, 2006. - 227 с.

8. Морозова В. Т. Гематологические исследования в диагностике заболеваний / В. Т. Морозова // Клин. лаб. диагностика. - 1996. - № 6. - С. 3-7.

9. Особенности реактивных свойств сердечнососудистой системы как отражение эффективности адаптационных реакций у лиц с аритмическим синдромом инволютивного характера / В. Г. Самохвалов, О. Д. Булынина, С. Д. Прасол [и др.] // Медицина сьогодні і завтра. - 2010. - № 2-3. - Вип. 47-48. C. $120-122$.

10. Протокол лікування залізодефіцитної анемії у дітей : наказ МОЗ України № 9 від 10.01.2005 р. [Електронний ресурc]. - Режим доступу : http://www.moz.gov.ua. - Назва з екрану

11. Тарасова И. С. Причины железодефицитных состояний у подростков / И. С. Тарасова, М. В. Красильникова, Н. С. Сметанина // Вопросы современной педиатрии. - 2006. - Т. 5, № 1. - С. 571.

12. Чермит К. Д. Гармоническая пара «симметрия-асимметрия» в организме человека как фундаментальная основа адаптации : автореф. дис. ... д-ра биол. наук / К. Д. Чермит. - Краснодар, 2004. -49 с.

13. Щербатюк Н. Ю. Вплив дефіциту заліза на функціональний стан серцево-судинної системи у дітей / Н. Ю. Щербатюк // Проблеми екології та медицини. - 1998. - Т. 2, № 3-4. - С. 66.

14. Щербинина С. П. Диагностическое значение комплексного исследования показателей метаболизма железа в клинической практике / С. П. Щербинина // Гематология и трансфузиология. - 2005. - № 5. C. 23-28.

15. Boothby L. Vitamin C and vitamin E for Alzheimer's disease / L. Boothby, P. Doering // Ann. Pharmacother. 2005. - V. 39, № 12. - P. 1073-1080.

16. Hercberg S. Iron deficiency in Europe / S. Hercberg, P. Preziosi, P. Galan // Public Health Nutr. - 2001. Vol. 4 (2). - P. 537-545.

Качинская Татьяна, Монюк Людмила. Влияние содержания гемоглобина в крови на кардиореспираторную систему женщин. Цель работы - изучении влияние различного содержания гемоглобина в крови на функциональное состояние кардиореспираторной системы женщин зрелого возраста. Исследование проведено на 30 женщинах в возрасте 28-32 лет. Все испытуемые разделены на три группы: I - контрольная группа, женщины (10 человек) с нормальным содержанием гемоглобина в крови; II - женщины (10 человек) с железодефицитной анемией; III - женщины (10 человек) с $\mathrm{B}_{12}$-фолиево-дефицитной анемией. Определение концентрации гемоглобина в крови испытуемых проводили цианметгемоглобиновим фотометрическим методом. Адаптационные и резервные возможности сердечно-сосудистой системы характеризовались лучшими показателями у лиц с $\mathrm{B}_{12}$-фолиеводефицитной анемией и нормальным содержанием гемоглобина, по сравнению с женщинами с железодефицитной анемией. По пробе Штанге женщины контрольной группы и с $\mathrm{B}_{12}$-фолиеводефицитной анемией характеризуются хорошим уровнем функционального состояния дыхательной системы, тогда как испытуемые с ЖДА - средним. По показателям теста Генчи, согласно оценочной шкале, уровень возможностей оценивается как средний, у лиц II и III групп и нормальный - у женщин контрольной группы.

Ключевые слова: железодефицитная анемия, $\mathrm{B}_{12}$-фолиеводефицитная анемия, гемоглобин.

Kachynska Tetiana, Monuk Lyudmila. Influence of Hemoglobin in the Blood of Women on the Cardiorespiratory System. The purpose of the work was to study the effect of different hemoglobin in the blood on the functional state of the cardio-respiratory system of adult women. The study was conducted on 30 women aged 28-32 years. All subjects were divided into three groups: I - control group, women (10 persons) with normal blood hemoglobin; II - 
female (10 persons) with iron deficiency anemia; III - female (10 persons) with $\mathrm{B}_{12}$-folic acid-deficiency anemia. Determination of the concentration of hemoglobin in the blood test was carried out photometrically tsianmetgemoglobinovim. Adaptable and reserve the possibility of cardiovascular system characterized by the best performance in people with vitamin $\mathrm{B}_{12}$-folic acid deficiency anemia and normal hemoglobin compared to women with iron deficiency anemia. Female in the control group and $\mathrm{B}_{12}$-folic acid deficiency anemia are characterized by a good level of functional state of the respiratory system, whereas subjects with IDA-average.

Key words: iron deficiency anemia, $\mathrm{B}_{12}$-folic acid-deficiency anemia, hemoglobin.

Стаття надійшла до редколегії 29.09.2016 р.

УДК 612.821:612 82/.83

\author{
Сергій Тукаєв, \\ Світлана Федорчук, \\ Людмила Чікіна, \\ Таїсія Герасько, \\ Ігор Зима, \\ Олександр Зайченко, \\ Юрій Гаврилець, \\ Володимир Різун, \\ Володимир Богданов, \\ Юрій Горго
}

\title{
Статичні електричні потенціали в біологічно активних зонах шкіри обличчя за умов формування емоційного вигорання в студентів
}

Статичні електричні потенціали (СТЕП) у біологічно активних зонах шкіри (БАЗ) відображають рівень фонової активації мозкових структур і рівень психічного стресу. Мета дослідження - виявити зв'язки СТЕП у симетричних біологічно активних зонах шкіри обличчя з рівнем емоційного вигорання в студентів. Виявлена зворотна кореляція між формуванням емоційного вигорання й рівнем електричного потенціалу шкіри в правих білявушних БАЗ $\left(\mathrm{r}_{s}=-.43, \mathrm{p}<.05\right)$ відносно долоні як референтної ділянки. Знайдено кореляції між розвитком стадії опору вигоранню та фоновими СТЕП у правих і лівих лобних БАЗ (відповідно, $\mathrm{r}_{s}=-.44$ i $\mathrm{r}_{s}$ $=-.47, \mathrm{p}<.05)$ і СТЕП у лівій лобній БАЗ після впливу негативних кадрів телевізійних новин $\left(\mathrm{r}_{s}=-.50, \mathrm{p}<.01\right)$. Це вказує на те, що формування емоційного вигорання знижує передпускову (до початку експерименту) емоційну напругу й відповідь, тобто силу реакції, на «зовнішні» негативні емоційні стимули. Отримані дані свідчать про те, що електродермальні потенціали можуть служити об'єктивними критеріями формування емоційного вигорання.

Ключові слова: статичні електричні потенціали (СТЕП), біологічно активні зони шкіри людини (БАЗ), рівень емоційного вигорання

Постановка наукової проблеми та її значення. Висока реактивність нервової системи часто є причиною неадекватної реакції організму на різні за силою подразники й лежить в основі тривожності особистості, яка в сукупності з високою емоційністю знижує надійність та ефективність розумової діяльності людини $[1 ; 2 ; 3]$, соціальну мотивацію й соціальні взаємодії особливо в ситуаціях неконтрольованого стресу [4; 5; 6]. Як відомо, одна 3 форм стресу - емоційне вигорання. Найбільш уразливими до вигорання особистості, які реагують на стрес агресивно [7; 8]. Проте на початку формування емоційного вигорання агресивність дає змогу зменшити негативний вплив емоційного стресу [7]. Ризик розвитку вигорання також збільшують такі особистісні риси: нейротизм, тривожність, низька самосвідомість, емоційна нестійкість [7; 9]. За тривалого розвитку емо-

(C) Тукаєв С., Федорчук С., Чікіна Л., Герасько Т., Зима І., Зайченко О., Гаврилейь Ю., Різун В., Богданов В., Горго Ю., 2016 